\title{
PENGARUH PEMBERIAN PROPOLIS LEBAH TERHADAP GAMBARAN HISTOPATOLOGI HEPAR MENCIT (Mus musculus) BETINA YANG DIPAPAR LOGAM BERAT PB ASETAT $\left[\mathrm{Pb}\left(\mathrm{C}_{2} \mathrm{H}_{3} \mathrm{O}_{2}\right)_{2}\right]$
}

\section{THE EFFECT OF BEE PROPOLIS ON LIVER HISTOPATHOLOGY OF MICE (Mus musculus) FEMALE WHICH EXPOSURED BY LEAD ACETATE $\left[\mathrm{Pb}\left(\mathrm{C}_{2} \mathrm{H}_{3} \mathrm{O}_{2}\right)_{2}\right]$}

\author{
Sartika Dewi Rachmani 1), Erma Safitri 2), Roesno Darsono 2), Eka Pramyrtha H. 2), \\ Hani Plumeriastuti 2), Kuncoro Puguh S. 2) \\ 1) Mahasiswa, 2) Dosen \\ Fakultas Kedokteran Hewan Universitas Airlangga \\ Kampus C UNAIR, Jl. Mulyorejo-Surabaya 60115 \\ Telp. 031-5992785, Fax. 031-5993015 \\ Email: jbmvunair@gmail.com
}

\begin{abstract}
Lead acetate in the hepatobiliary system may cause peroxidation catalysis of unsaturated fatty acids, reduce nitrogenoxide and increase hydroxyl radical. Lead acetate produces oxidative stress characterized by free radical formation and inhibits lipid peroxidation. Giving antioxidants can neutralize free radicals from the detrimental effects that arise on the process or excess oxidation reactions. The purpose of this research was to find out how the effect of bee propolis on histopathologic images of hepatic mice (Mus musculus) of females exposed to lead acetate $\left[\mathrm{Pb}\left(\mathrm{C}_{2} \mathrm{H}_{3} \mathrm{O}_{2}\right)_{2}\right]$. The subjects were 25 mice (Mus musculus) mushulus of BALB/C strain with average weight 25-30 gram and 8 weeks old, divided into 5 treatment groups, each consisting of 5 heads per group. The K- group was given a Tween 80 solution at a doses of $0.5 \mathrm{mg} / \mathrm{kgBW}$ for 20 consecutive days. The $\mathrm{K}+$ group, which was given only lead acetate at a doses of $10 \mathrm{mg} / \mathrm{kgBW}$ orally for 10 days. P1, P2, and P3 were given $10 \mathrm{mg} / \mathrm{kgBW}$ lead acetate solution orally for 10 days. The following 10 days were given bee propolis with doses of P1 $200 \mathrm{mg} / \mathrm{kgBW}$, P2 400 $\mathrm{mg} / \mathrm{kgBW}$, and P3 $800 \mathrm{mg} / \mathrm{kgBW}$. On the 21th days the mice were dissected, to observe the extent of the damage. All data were performed using a statistical test with Kruskal Wallis test and if there was a marked difference between treatment groups $(p<0.05)$, then the Mann-Whitney test was followed. The results obtained that bee propolis can repair hepatic cell damage in mice (Mus musculus) of females exposed to lead acetate. Increased dose of bee propolis is ineffective in repairing hepatic cell damage in mice (Mus musculus) of females exposed to lead acetate.
\end{abstract}

Key words: bee propolis, lead acetate, liver histophatology, female mice

\section{PENDAHULUAN}

Seiring dengan perkembangan zaman terjadi peningkatan proses industrialisasi baik di negara maju maupun berkembang seperti Indonesia. Peningkatan proses industrialisasi berakibat pada peningkatan pencemaran logam berat, hal ini menjadi masalah yang cukup serius. Logam berat seperti timbal (Pb asetat) yang mencemari lingkungan merupakan zat yang toksik bagi manusia dan hewan. Hasil penelitian lain di Yogyakarta pada tahun 2008 menyebutkan terdapat 29.234 kasus penurunan IQ pada anak sebagai dampak kesehatan yang disebabkan oleh timbal (Gravitiani, 2009). Wilayah Indonesia dimana sebagian besar merupakan wilayah perairan sangat rentan terhadap dampak pencemaran salah satunya logam berat (Athena dkk., 1996; Kurniasih, 2002; dan Riyatun dkk., 2004). 
Pabrik industri yang dibangun dengan tidak mengikuti system Instalasi Pengolahan Air dan Limbah (IPAL) yang memadai, akan berakibat pada peningkatan limbah yang dibuang ke lingkungan. Salah satu limbah logam berat dari banyak jenis yang menjadi pencemar lingkungan adalah timbal (Wardhayani, 2006). Timbal dapat masuk dalam tubuh mahluk hidup melalui saluran pencernaan (gastrointestinal), saluran pernafasan (inhalasi), dan penetrasi melalui kulit (topikal), baik secara langsung maupun tidak langsung. Makanan dan minuman terpapar timbal yang dapat berasal dari kontaminasi pipa, solder, kran dan kontaminasi kaleng minuman dan makanan yang mengandung timbal (Dedy, 2008).

Toksisitas $\mathrm{Pb}$ terutama memberikan dampak yang berat pada organ-organ penting pada makhluk hidup misalnya pada hepar dan ginjal (Darmono, 2001). Salah satu organ yang mengalami perubahan akibat paparan timbal yang berlebihan adalah hepar. Hepar merupakan organ tubuh terbesar dan organ metabolisme yang paling kompleks di dalam tubuh. Organ ini terlibat dalam metabolisme zat makanan serta sebagian besar obat dan toksikan (Lu, 1995). Menurut Santosa (2005) apabila senyawa racun yang masuk terlalu besar sehingga bersifat toksis pada hepar, maka akan menimbulkan degenerasi jaringan hepar, bahkan sampai terjadi nekrosis yang dapat merusak jaringan hepar. Timbal dalam darah dapat menyebabkan kerusakan berbagai organ termasuk organ hepar. Hepar berperan dalam melakukan proses metabolisme dan detoksifikasi untuk menetralkan senyawa yang bersifat racun dalam tubuh, adapun mekanisme kerusakan hepar oleh $\mathrm{Pb}$ dapat terjadi akibat meningkatnya radikal bebas dan penurunan kemampuan sistem antioksidan tubuh sehingga memicu stres oksidatif (Gurer and Ercal, 2000). Untuk melindungi hepar dari kerusakan tersebut, maka diperlukan zat yang mampu melawan radikal bebas akibat paparan $\mathrm{Pb}$, yaitu dengan antioksidan (Adams and Angulo, 2006).

Kandungan antioksidan yang tinggi terdapat pada propolis. Komponen utama dari propolis adalah flavonoid dan asam fenolat, termasuk Caffeic Acid Phenetyl Ester (CAPE). Penelitian di Jepang menunjukkan bahwa kandungan CAPE yang ada di dalam propolis mempunyai aktivitas antioksidan yang tinggi, yang dapat meningkatkan ekspresi glucose-6phosphate dehydrogenase (G6PD) yang didapat dari ekspresi gen antioksidan, lebih kuat dibandingkan vitamin $\mathrm{E}$. CAPE mempunyai aktivitas antioksidan 4-6 kali lebih kuat terhadap oksidan seperti $\mathrm{H}_{2} \mathrm{O}_{2}$ dan radikal bebas dibandingkan vitamin $\mathrm{C}$ dan $\mathrm{N}$-acctylcystein (NAC) (Nakajima, 2009).

Propolis terbukti memiliki efek hepatoprotektor yang baik, namun belum diketahui pengaruh pemberian propolis terhadap gambaran histopatologi hepar mencit (Mus musculus) betina yang dipapar logam berat $\mathrm{Pb}$ asetat $\left[\mathrm{Pb}\left(\mathrm{C}_{2} \mathrm{H}_{3} \mathrm{O}_{2}\right)_{2}\right]$.

\section{RUMUSAN MASALAH}

Berdasarkan latar belakang
penelitian diatas maka dapat
dirumuskan permasalahan yaitu:
bagaimana pengaruh pemberian
propolis lebah terhadap gambaran
histopatologi hepar mencit (Mus
musculus) betina yang dipapar logam
berat $\mathrm{Pb}$ asetat $\left[\mathrm{Pb}\left(\mathrm{C}_{2} \mathrm{H}_{3} \mathrm{O}_{2}\right)_{2}\right]$ ?

\section{TUJUAN PENELITIAN}

Penelitian ini bertujuan untuk mengetahui pengaruh pemberian propolis lebah terhadap gambaran histopatologi hepar mencit (Mus musculus) betina yang dipapar logam berat $\mathrm{Pb}$ asetat $\left[\mathrm{Pb}\left(\mathrm{C}_{2} \mathrm{H}_{3} \mathrm{O}_{2}\right)_{2}\right]$. 


\section{MANFAAT HASIL PENELITIAN}

Penelitian ini diharapkan dapat membuka pengetahuan baru bahwa propolis yang terkandung di dalam propolis lebah dapat digunakan sebagai pilihan alternatif dan pilihan obat alami pada gangguan hepar akibat logam berat $\mathrm{Pb}$ asetat $\left[\mathrm{Pb}\left(\mathrm{C}_{2} \mathrm{H}_{3} \mathrm{O}_{2}\right)_{2}\right]$.

\section{METODE PENELITIAN}

\section{TEMPAT DAN WAKTU PENELITIAN}

Penelitian ini dilaksanakan di kandang hewan coba dan Laboratorium Patologi Veteriner Fakultas Kedokteran Hewan Universitas Airlangga Surabaya. Penelitian ini dilakukan mulai bulan Maret 2018 sampai April 2018.

\section{HEWAN PERCOBAAN}

Penelitian ini menggunakan 25 ekor mencit (Mus musculus) betina strain BALB/C dengan berat rata-rata 25-30 gram dan berumur 8 minggu.

\section{PROSEDUR PENELITIAN}

\section{PEMBUATAN PROPOLIS LEBAH}

Tablet propolis lebah dihaluskan sampai halus dan homogen menggunakan mortar dan stamper. Setelah itu tambahkan dengan tween 80 $1 \%$ sebagai suspensator.

\section{PENENTUAN DOSIS}

Pada penelitian ini hewan yang telah dikelompokkan menjadi lima kelompok diberikan untuk pengobatan secara per oral. Pemberian dosis $\mathrm{Pb}$ asetat pada penelitian ini sebanyak 10 $\mathrm{mg} / \mathrm{kgBB} /$ hari (Azarnia et al., 2004). Untuk dosis Bee Propolis yang digunakan dalam penelitian ini adalah $200 \mathrm{mg} / \mathrm{kgBB}$ untuk kelompok P1, 400 $\mathrm{mg} / \mathrm{kgBB}$ untuk kelompok P2, dan 800 $\mathrm{mg} / \mathrm{kgBB}$ untuk kelompok P3 (Lopes et al., 2013).

\section{PERLAKUAN}

K (-) : Kelompok kontrol, hanya diberi Tween $80 \quad 0,5 \mathrm{ml} /$ ekor/hari selama 20 hari.

$\mathrm{K}(+)$ : Larutan $\mathrm{Pb}$ asetat $10 \mathrm{mg} / \mathrm{kgBB}$ selama 10 hari.

$\mathrm{P}$ (1) : Larutan $\mathrm{Pb}$ asetat $10 \mathrm{mg} / \mathrm{kgBB}$ selama 10 hari + Bee Propolis $200 \mathrm{mg} / \mathrm{kgBB}$ selama 10 hari.

$\mathrm{P}(2)$ : Larutan $\mathrm{Pb}$ asetat $10 \mathrm{mg} / \mathrm{kgBB}$ selama 10 hari + Bee Propolis $400 \mathrm{mg} / \mathrm{kgBB}$ selama 10 hari.

$\mathrm{P}$ (3) : Larutan $\mathrm{Pb}$ asetat $10 \mathrm{mg} / \mathrm{kgBB}$ selama 10 hari + Bee Propolis $800 \mathrm{mg} / \mathrm{kgBB}$ selama 10 hari.

\section{PENGAMATAN HISTOPATOLOGI HEPAR}

Pemeriksaan preparat histopatologi hepar dilakukan dengan mengamati lesi dengan vena sentralis berada ditengah-tengah lapang pandang dan menggunakan mikroskop cahaya perbesaran 400x. Kemudian dilakukan penilaian derajat kerusakan hepar. Penilaian derajat kerusakan hepar menggunakan metode scoring Brunt et al., (1999) berdasarkan persen terjadinya degenerasi dan nekrosis (Tabel 3.1)

Tabel 3.1 skor penilaian derajat histopatologi sel hepar (sumber: Brunt et al., 1999)

\begin{tabular}{|l|c|c|}
\hline & Degenerasi & Nekrosis \\
\hline Tidak ada & 0 & 0 \\
\hline $\begin{array}{l}\text { Minimal } \\
(0-25 \%)\end{array}$ & 1 & 1 \\
\hline $\begin{array}{l}\text { Ringan } \\
(25-50 \%)\end{array}$ & 2 & 2 \\
\hline $\begin{array}{l}\text { Sedang } \\
(50-75 \%)\end{array}$ & 3 & 3 \\
\hline $\begin{array}{l}\text { Berat } \\
(75-100 \%)\end{array}$ & 4 & 4 \\
\hline
\end{tabular}




\section{ANALISIS DATA}

Data yang diperoleh berupa skor nilai gambaran histopatologi yang meliputi degenerasi dan nekrosis hepatosit mencit yang disusun dalam betuk tabel kemudian dilakukan analisis statistik. Analisis data dilakukan uji statistik dengan menggunakan uji Kruskal Wallis dan bila terdapat perbedaan yang nyata diantara kelompok perlakuan $(p<0,05)$, maka dilanjutkan dengan uji Mann-Whitney (Daniel, 1991). Seluruh analisis tersebut dikerjakan dengan program komputer SPSS 18.0 Windows.

\section{HASIL DAN PEMBAHASAN}

Berdasarkan hasil pengamatan mikroskopis, didapatkan hasil analisis statistik untuk degenerasi dan nekrosis sel hepatosit sebagai berikut:

Tabel 4.1 Nilai mean tingkat degenerasi sel hepatosit

\begin{tabular}{|c|c|}
\hline Perlakuan & Mean Rank \pm SD \\
\hline K- & $3,00^{\mathrm{a}} \pm 1,3254$ \\
\hline K+ & $23,00^{\mathrm{d}} \pm 1,4583$ \\
\hline P1 & $15,70^{\mathrm{c}} \pm 1,2288$ \\
\hline P2 & $15,30^{\mathrm{c}} \pm 1,0832$ \\
\hline P3 & $8,00^{\mathrm{b}} \pm 1,4720$ \\
\hline
\end{tabular}

a, b, c, d: superskrip yang berbeda pada kolom yang sama menunjukkan perbedaan yang signifikan.

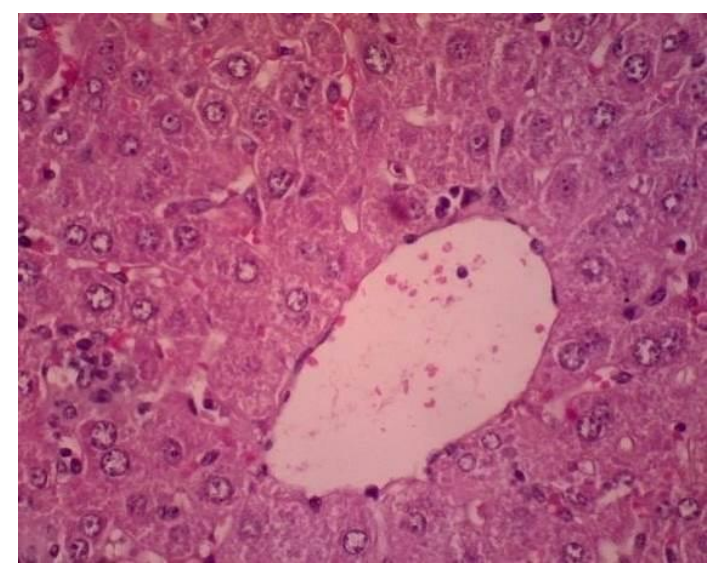

Gambar 4.2 Gambaran histopatologi Degenerasi pada hepar mencit betina. Degenerasi Hidrofik (Pewarnaan H.E; perbesaran 400x; Mikroskop Cahaya Olympus ${ }^{\circledR}$ CX-41).

Tabel 4.2 Nilai mean tingkat nekrosis sel hepatosit

\begin{tabular}{|c|c|}
\hline Perlakuan & Mean Rank \pm SD \\
\hline K- & $6,00^{\mathrm{a}} \pm 0,4359$ \\
\hline K+ & $23,00^{\mathrm{d}} \pm 0,4899$ \\
\hline P1 & $17,60^{\mathrm{c}} \pm 0,5228$ \\
\hline P2 & $12,40^{\mathrm{b}} \pm 1,0755$ \\
\hline P3 & $6,00^{\mathrm{a}} \pm 0,4899$ \\
\hline
\end{tabular}

a, b, c, d: superskrip yang berbeda pada kolom yang sama menunjukkan perbedaan yang signifikan.

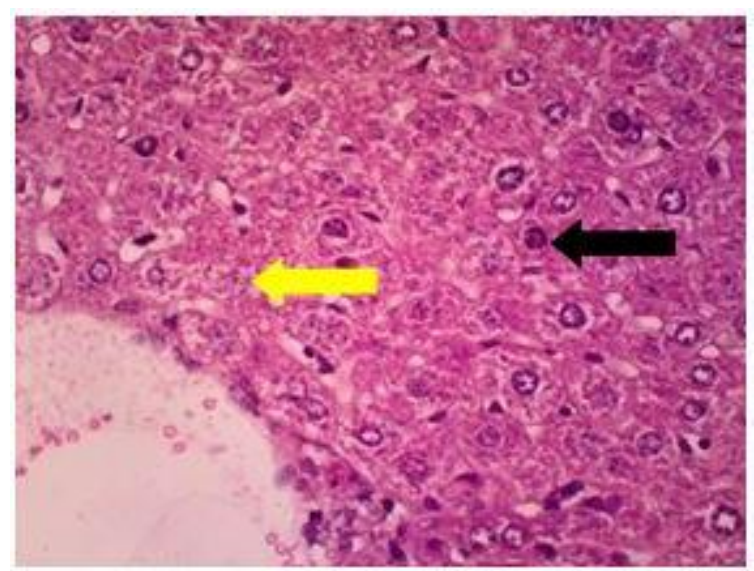

Gambar 4.3 Gambaran histopatologi Nekrosis pada hepar mencit betina. Dapat terlihat pada gambar (

$\Rightarrow$ ) piknotis ( $\longrightarrow$ ) kariolisis (Pewarnaan H.E; perbesaran 400x; Mikroskop Olympus ${ }^{\circledR}$ CX-41).

Tabel (4.1) dan tabel (4.2) menunjukkan apabila bahwa semakin tinggi tingkat kerusakan yang ditimbulkan $\mathrm{Pb}$ asetat, semakin tinggi pula skor penilaian derajat kerusakan degenerasi dan nekrosis yang dihasilkan. 
Kelompok perlakuan K- yaitu tanpa dipapar logam berat $\mathrm{Pb}$ asetat dan tanpa diberikan propolis lebah, kondisi hepar normal karena sel hepatosit tidak mengalami jejas, inti sel nampak berwarna biru dan sitoplasma tampak berwarna keunguan karena bersifat eosinofilik. Kelompok perlakuan $\mathrm{K}+$ yang tanpa diberikan propolis lebah namun dipapar logam berat $\mathrm{Pb}$ asetat 10 $\mathrm{mg} / \mathrm{kgBB}$ menunjukkan kelainan patologi degenerasi tertinggi dengan skor 4 artinya degenerasi dan nekrosis terjadi pada $75 \%-100 \%$ dari seluruh lapangan pandang dibandingkan dengan kelompok perlakuan yang lainnya. Timbal yang masuk kedalam tubuh melalui saluran pencernaan akan diabsorbsi oleh usus untuk dimetabolisme di hepar. Vena porta membawa darah deoksigenasi dan zat toksik timbal yang diabsorbsi dari usus. Cabang dari vena porta membawa darah tersebut ke sinusoid yang kemudian diterima oleh sel hepar. Timbal dalam sel hepatosit dapat menginduksi pembentukan radikal bebas dan menurunkan kemampuan sistem antioksidan tubuh sehingga terjadi stres oksidatif. Menurut penelitian Jin et al., (2008) mencit yang diberi logam berat $\mathrm{Pb}$ asetat dosis 10 $\mathrm{mg} / \mathrm{kg}$ BB secara oral dapat memicu timbulnya stress oksidatif. Stres oksidatif memicu pembentukan radikal bebas yaitu Reactive Oxygen Species (ROS) yang dapat bereaksi dan menyebabkan kerusakan pada banyak molekul di dalam sel. Perusakan sel akibat ROS didahului oleh kerusakan membran sel antara lain mengubah fluiditas, struktur dan fungsi membran sel (Sipos et al., 2003). Radikal bebas berikatan dengan lipid dari membran sel hepatosit dan membentuk peroksidasi lipid. Konsekuensi penting dari peroksidasi lipid adalah meningkatnya permeabilitas membran yang dapat mengganggu proses pompa ion $\mathrm{Ca}^{2+}$ dan hambatan terhadap proses pompa ion $\mathrm{Na}^{+}$dan $\mathrm{K}^{+}$di dalam sel sehingga terjadi degenerasi pada sel karena gangguan homeostasis. Keadaan sel yang mengalami gangguan tersebut dapat menyebabkan keadaan di dalam sel lebih pekat dan bersifat hipotonis sedangkan keadaan ekstraseluler menjadi hipertonis sehingga cairan yang berada pada ekstraseluler masuk ke dalam intraseluler dan menyebabkan gangguan patologi yang biasa disebut degenerasi hidrofik. Secara umum degenerasi dikarenakan adanya penerunan kemampuan sistem pompa ion $\mathrm{Na}^{+}$dalam sel yang menyebabkan pembengkakan sel dan degenerasi keruh (Krisnasari dkk, 2014).

Kelompok perlakuan P1 dosis 200 $\mathrm{mg} / \mathrm{kgBB}$ juga menunjukkan adanya kerusakan jaringan berupa degenerasi, namun degenerasi yang terjadi tidak sebanyak perlakuan $\mathrm{K}+$ yang hanyak dipapar logam berat $\mathrm{Pb}$ asetat. Pada kelompok P1 yang diberi propolis lebah $200 \mathrm{mg} / \mathrm{kgBB}$ tampak histopatologi hepar berupa degenerasi hidrofik. Degenerasi hidrofik merupakan jejas yang reversible. Peran propolis lebah pada konsentrasi $200 \mathrm{mg} / \mathrm{kgBB}$ telah dapat memperbaiki jejas sel yang reversibel, namun disini belum mencapai keadaan normal. Perubahan yang terjadi adalah sel hepatosit nampak membengkak berisi cairan, inti sel masih terlihat jelas dan jaringan hepar masih dapat dikenali (Robbins and Vinay, 2010). Hal ini dikarenakan pada pengamatan histopatologi sel hepatosit pada perlakuan P1 yang diberi propolis lebah $200 \mathrm{mg} / \mathrm{kgBB}$ serupa dengan perlakuan $\mathrm{K}+$ yang hanya dipapar logam berat $\mathrm{Pb}$ asetat 10 $\mathrm{mg} / \mathrm{kgBB}$ yaitu masih banyak ditemukan adanya degenerasi hidrofik pada beberapa bagian dari keseluruhan lapangan pandang. Sel-sel hepatosit nampak membesar dan mendesak sinusoid. Sitoplasma sel tampak keruh dan pucat. Hal tersebut terjadi karena jumlah zat aktif yang berperan sebagai antioksidan dalam propolis lebah pada 
dosis tersebut masih belum cukup efektif untuk melawan radikal bebas.

Pada kelompok perlakuan P2 yang diberikan propolis lebah dengan 400 $\mathrm{mg} / \mathrm{kgBB}$ masih terlihat adanya degenerasi hidrofik disebabkan terganggunya metabolisme energi dalam sel atau karena cedera pada membran sel sehingga sel tidak mampu memompa ion $\mathrm{Na}+$ yang cukup (Ressang, 1984), tetapi jumlahnya tidak sebanyak kelompok perlakuan sebelumnya. Kelompok perlakuan P3 yang diberikan propolis lebah 800 $\mathrm{mg} / \mathrm{kgBB}$ terjadi degenerasi ringan. Peran propolis lebah pada konsentrasi ini telah dapat memperbaiki jejas sel yang reversibel, dikarenakan keadaannya hampir mencapai normal. Propolis lebah mengandung flavonoid. Senyawa flavonoid berperan dalam aktivitas antioksidan, yaitu dengan menghambat dihasilkannya agen oksidatif seperti Reactive Oxygen Species (ROS) oleh sel darah perifer, atau dengan menghambat paparan oksidatif dalam tubuh yang melindungi lipid dan protein agar tidak berubah menjadi lipid peroksida. Kedua mekanisme itu membuat flavonoid memiliki beberapa efek, diantaranya menghambat peroksidase lipid, menahan kerusakan jaringan oleh radikal bebas (Krisnatuti dan Yenrina, 2005).

Pada kelompok $\mathrm{K}+$ yang hanya dipapar logam berat $\mathrm{Pb}$ asetat 10 $\mathrm{mg} / \mathrm{kgBB}$ mengalami nekrosis paling parah dengan nilai skor 4 artinya nekrosis terjadi pada $75 \%-100 \%$ dari seluruh lapangan pandang, terjadi kematian sel yang bersifat irreversible yaitu kariolisis. Inti sel menjadi hilang sehingga pada gambar tampak sebagai sel yang kosong (Wulandari, 2006). Apabila darah dari vena porta banyak membawa racun atau toksin, maka zona pertama paling dekat dengan sumber pasokan darah yang pertama kali terkena zat toksik tersebut sehingga kerusakan sel paling banyak ditemukan pada sekitar portalis (Arimbi dkk., 2013).

Pada kelompok perlakuan K- yang tanpa dipapar logam berat $\mathrm{Pb}$ asetat dan propolis lebah, P1 yang diberi propolis lebah $200 \mathrm{mg} / \mathrm{kgBB}$ dan P2 yang diberi propolis lebah $400 \mathrm{mg} / \mathrm{kgBB}$ masih terlihat adanya nekrosis, tetapi dalam jumlah yang sedikit, tidak merata, bahkan di beberapa tempat nekrosis tidak terjadi sehingga skor yang didapat adalah 0. Pada kelompok perlakuan P3 yang diberi propolis lebah $800 \mathrm{mg} / \mathrm{kgBB}$ tidak ditemukan adanya kerusakan jaringan berupa nekrosis, hal tersebut dikarenakan peran propolis lebah 800 $\mathrm{mg} / \mathrm{kgBB}$ telah dapat memperbaiki jejas sel sama halnya dengan antibiotik sehingga kematian sel yang bersifat irreversible dapat dicegah.

Propolis lebah dapat berfungsi untuk memperbaiki kondisi patologi dari bagian tubuh yang sakit, bekerja sebagai antioksidan dan antibiotik serta meningkatkan sistem kekebalan tubuh baik humoral maupun seluler karena mengandung flavonoid sekitar 15\% (Krell, 1996). Daya antioksidan menggambarkan besarnya potensi propolis lebah untuk berperan sebagai antioksidan. Antioksidan yang ada dapat meredam dampak negatif dari oksidan dengan cara memberikan elektronnya pada oksidan, antioksidan tersebut mampu mencegah dan meregenerasi kerusakan sel akibat radikal bebas (Widjaja, 1997).

\section{KESIMPULAN}

Berdasarkan penelitian yang telah dilakukan, dapat diperoleh kesimpulan bahwa pemberian propolis lebah memberikan pengaruh yang dapat memperbaiki sel hepatosit dari kerusakan akibat paparan logam berat $\mathrm{Pb}$ asetat. Pemberian propolis lebah dengan dosis $800 \mathrm{mg} / \mathrm{kgBB}$ paling baik memperbaiki sel hepatosit dari kerusakan akibat paparan logam berat $\mathrm{Pb}$ asetat. 


\section{DAFTAR PUSTAKA}

Adams, L.A., Angulo, P. 2006. Treatment of non-alcoholic fatty liver disease. Postgrad med J. 82: $315-22$

Arimbi., Azmijah, A., Darsono, R., Plumeriastuti, H., Widiyatno, T.V., Legowo, D. 2013. Buku Ajar Patologi Umum Veteriner. Airlangga University Press. Surabaya. 9-10.

Athena, A.T., Tugaswati, dan Sukar. 1996. Kandungan Logam Berat $(\mathrm{Hg}$, $\mathrm{Cd}$ dan $\mathrm{Pb})$ Dalam Air Tanah Pada Perumahan Tipe Kecil di Jabodetabek. Buletin Penelitian Kesehatan 24(4): 18-27.

Azarnia, M.; Shakour, A.; Rostami, P. \& Sanaie-Mehr, A. 2004. The protective role of L-cysteine against follicular atresia induced by lead in mouse ovary. J. Acta. Medica. Iranica., 42(2): 83-88.

Brunt, E.M., C.G, Janney., A.M, Di Bisceglie., B.A.N, Tetri and B.R, Bacon. 1999. Nonalcoholic Steatohepatitis. A Proposal for Grading and Staging The Histologic Lesions.

Daniel, W.W. 1991. Statistik Non Parametrik Terapan. Alih Bahasa: Alex Tri Kantjono. Penerbit PT. Gramedia. Jakarta. 272-275.

Darmono. 2001. Lingkungan Hidup dan Pencemaran. Hubungannya dengan Toksikologi Senyawa Logam. Penerbit Universitas Indonesia (UI Press). hlm. 109 112, 140.
Dedy, S. 2008. Pengaruh Proteksi Vitamin C Terhadap Enzim Transminaze dan Gambaran Histopatologi Hepar Mencit yang Dipapar Plumbum (Tesis). Sumatra Utara: Universitas Sumatera Utara.

Gravitiani, E. 2009. Valuasi ekonomi dampak timbal $(\mathrm{Pb})$ gas buang kendaraan bermotor terhadap kesehatan masyarakat perkotaan Yogyakarta. Universitas Gajah Mada. Disertasi.

Gurer, H. and N. Ercal. 2000. Can Antioxidants be Beneficial in The Treatment of Lead Poisoning. Free Radical Biology and Medicine. 29 (10): 927-945.

Jin, X., Ling-jun, L., Chen W., Xiaofeng, W., Wen-yu, F. and Lihong, X. 2008. Lead Induces Oxidative Stress, DNA Damage and Alteration of P53, Bax and Bcl-2 Expressions in Mice. Food and Chemical Toxicology 46. 1488-1494.

Krisnasari D., K. Diah, S. Hidayat, dan R. B. A. Viva. 2014. Efek Propolis Terhadap Fungsi dan Perlemakan Hati Tikus Putih (Rattus Norvegicu) Model Hiperkolesterolemia. Jurusan Kedokteran FKIK. Universitas Jendral Soedirman. Purwokerto.

Krisnatuti, D. dan Yenrina, S. 2005. Menyiapkan Makanan Pendamping Asi. Pustaka Swara. Jakarta. 
Lopes, A. A., Ferreira, T. S., Nesi, R. T., Lanzetti, M., Pires, K. M. P., Silva. A. M., Borges, R. M., Silva, A. J. R., Valença, S. S., Porto, L. C. 2013. Antioxidant action of propolis on mouse lungs exposed to shortterm cigarette smoke. Elsevier. Bioorganic \& Medicinal Chemistry 21 (2013) 7570-7577.

Lu, F.C. 1995. Toksikologi Dasar, Azas, Organ Sasaran dan Penilaian Resiko. Edisi Kedua. Jakarta: Penerbit UI. Hal 224-235.

Nakajima, Y. 2009. Comparison of Bee Products Based on Assays of Antioxidant Capacities. BMC Complementary and Alternative Medicine.

Ressang, DVM, MD. 1984. Patologi Khusus Veteriner. Edisi Kedua. Team Leader IFAD Project: Bali Cattle Disease Investigation Unit, Denpassar, Bali, 45-46.

Robbins, S.L. and K., Vinay. 2010. Robbins and Cotran Pathologic Basis of Disease. Eight Edition. Chapter 1. Philadelphia Edisi 8. 663-668

Santosa, M.H. 2005. Uji Toksisitas Akut Dan Subakut Ekstrak Etanol Dan Ekstrak Air Kulit Batang Artocarpus Champeden Spreng Dengan Parameter Histopatologi Hati Mencit. Majalah Farmasi Airlangga. 91: 5.
Sipos, P., Szentmihalyi, K., Feher, E., Abaza, M., Szilagyi, M. and Blazovics, A. 2003. Some Effects of Lead Contamination on Liver and Gallbladder Bile. Acta Biologica Szegediensis. 47(1-4): 139-142.

Wardhayani, S. 2006. Analisis Risiko Pencemaran Bahan Toksik Timbal (Pb) Pada Sapi Potong Di Tempat Pembuangan Akhir (TPA) Sampah Jatibarang [Tesis]. Fakultas Kesehatan Lingkungan. Universitas Diponegoro.

Widjaja S. 1997. Antioksidan: Pertahanan Tubuh Terhadap Efek Oksidan dan Radikal Bebas. Maj. Ilm. Fak. Kedokt. Usakti. 16(1): 162.

Wulandari, T, Harini, M. Listyawati, S. 2007. Pengaruh Ekstrak Daun Sambiloto (Andrographis paniculata) terhadap Struktur Mikroanatomi Hepar dan Kadar Glutamat Piruvat Transaminase Serum Mencit (Mus musculus) yang Terpapar Diazinon. Jurusan Biologi FMIPA Universitas Sebelas Maret (UNS) Surakarta. Bioteknologi 4 (2): 53-58. 